\title{
Fatty Acid Evaluation of Seeds and Nuts by Spectroscopy and Chromatography
}

\author{
Sahri Yanti ${ }^{1,2}$, Dinar Suksmayu Saputri ${ }^{1,2}$, Hung-Yu Lin ${ }^{1}$, Yu-Chieh Chou $^{1}$, Dinesh Chandra Agrawal ${ }^{1}$, \\ Wei-Jyun Chien ${ }^{1, *}$ \\ ${ }^{1}$ Department of Applied Chemistry, Chaoyang University of Technology, 168, Jifeng E. Rd., Wufeng District, \\ Taichung City 413310, Taiwan \\ ${ }^{2}$ Department of Agricultural Technology, Sumbawa University of Technology, Olat Maras Rd. Sumbawa District, West \\ Nusa Tenggara, 84371, Indonesia
}

Received April 29, 2021; Revised June 19, 2021; Accepted July 20, 2021

\section{Cite This Paper in the following Citation Styles}

(a): [1] Sahri Yanti, Dinar Suksmayu Saputri, Hung-Yu Lin, Yu-Chieh Chou, Dinesh Chandra Agrawal, Wei-Jyun Chien, "Fatty Acid Evaluation of Seeds and Nuts by Spectroscopy and Chromatography," Food Science and Technology, Vol. 9, No. 7, pp. 58 - 68, 2021. DOI: 10.13189/fst.2021.090302.

(b): Sahri Yanti, Dinar Suksmayu Saputri, Hung-Yu Lin, Yu-Chieh Chou, Dinesh Chandra Agrawal, Wei-Jyun Chien (2021). Fatty Acid Evaluation of Seeds and Nuts by Spectroscopy and Chromatography. Food Science and Technology, 9(7), 58 - 68. DOI: 10.13189/fst.2021.090302.

Copyright $\odot 2021$ by authors, all rights reserved. Authors agree that this article remains permanently open access under the terms of the Creative Commons Attribution License 4.0 International License

\begin{abstract}
The study aimed to determine the oil content and identify fatty acid methyl esters such as stearate, palmitate, linolenate, linoleate, and oleate in seeds and nuts like candlenut, peanut, sesame, sunflower, and sacha inchi. Oil extraction was carried out using Soxtec $8000^{\mathrm{TM}}$ and n-hexane solvent. The samples were dried at $50^{\circ} \mathrm{C}$. The extraction conditions optimized were temperature $135^{\circ} \mathrm{C}$, $\mathrm{n}$-hexane $50 \mathrm{~mL}$, boiling time $40 \mathrm{~min}$, and total extraction time $115 \mathrm{~min}$. Identification of fatty acids was carried out using Attenuated Total Reflection (ATR), Nuclear Magnetic Resonance (NMR), and Gas
\end{abstract} Chromatography-Flames Ionization Detector (GC-FID). The oil percentage detected in each sample was candlenut (59.95\%), peanut (40.08\%), sesame (57.06\%), sunflower (43.97\%), and sacha inchi (51.71). The ATR results show that the flour of nuts and seeds has a strong vibrational frequency of the $\mathrm{O}-\mathrm{H}$ molecule. Linolenate was detected at a chemical shift of $0.975 \mathrm{ppm}$ in NMR spectra and was found in sacha inchi and candlenut. The ATR, NMR, and GC-FID results showed that all samples contained unsaturated fatty acids. Candlenut, peanut, sesame, and sacha inchi were rich in linoleate $(\omega-6)$ as much as $25.68 \%$, $20.15 \%, 26.38 \%$, and $20.73 \%$, respectively. Oleate was abundant in sesame $(21.87 \%)$ and sunflower $(16.78 \%)$. Linolenate was found only in sacha inchi $(22.88 \%)$. The maximum percentage of stearate was found in sunflower
(4.02\%) followed by sesame (2.96\%), candlenut $(1.81 \%)$, sacha inchi $(1.52 \%)$, and peanut $(0.71 \%)$. This research provides useful information on fatty acid profiles beneficial for health, especially stearic acid, which can substitute trans fatty acids harmful to health.

Keywords Fatty Acid, Soxtec, Spectroscopy, Chromatography

\section{Introduction}

Seeds and nuts rich in fatty acids have their prominence in the food and pharmaceutical industries. Consumption of nuts can reduce the potential for cardiovascular disease and reduce diabetes and prostate disease [1]. Depending on their degree of saturation/unsaturation in the carbon chain, fatty acid methyl esters can be divided into three classes; saturated fatty acid (SFA), monounsaturated fatty acid (MUFA), and polyunsaturated fatty acid (PUFA). Fatty acid methyl esters commonly found in vegetable oils are palmitate, stearate, oleate, linolenate, and linoleate [2]. Among all fatty acid methyl esters, linolenate is the main in vegetable oils [3]. Linolenate and linoleate are essential PUFAs [4]. 
Fatty acid methyl esters needed by the industry are linolenate $(\omega-3)$, linoleate $(\omega-6)$ [5], oleate $(\omega-9)$ [6], and stearate [6-8]. Stearic acid or stearate is an SFA found in palm oil and sunflower [6,9], Nymphaea pubescens seeds [10], Ocimum basilicum [5], candlenut [11, 12], sesame [13], Cactus opuntia dillenii [14], sacha inchi [15] and almond seeds [16]. Nymphaea pubescens seeds contain stearic acid as palm oil and peanut oil [10]. Most of the stearic acid is obtained from the sunflower growing at low-temperature conditions [17]. Besides, it also depends on plant breeding and industrial processing methods [4]. Stearic acid can replace trans fatty acids that can trigger cardiovascular disease [18], allergies, cancer, obesity, and even death [4]. Compared to stearate, linolenate has high reactivity and is less stable [19].

Attenuated Total Reflectance (ATR) is a vibration spectrophotometer for determining the structure of organic molecules. It is commonly performed at wavenumbers $670-4000 \mathrm{~cm}^{-1}[20,21]$. The ATR can be carried out on liquid or solid samples. Solid samples are ground into flour. The sample preparation is simple and short. Spectra ATR is similar to Fourier-transform infrared spectroscopy (FTIR). Both can identify the vibrational frequency of molecule bonds at the same wavenumber, but the intensity is relatively different [21]. The application of vibration spectrophotometers in fatty acids has been carried out on vegetable oils [22-26].

Chromatography can be used for the separation, identification, and determination of constituents in the sample. The sample is dissolved in either gas, solid, or supercritical fluid in the stationary phase. After that, sample is distributed in two phases, namely the stationary phase and the mobile phase. The constituents having a long retention time move slowly. The difference migration speed is read as peaks that can be analyzed quantitatively and qualitatively. Identification of samples using chromatography is based on retention times [27]. Gas chromatography performs with a partition between gas and liquid. The detector responds to separate constituents. The analyte concentration can be calculated from the peak area ratio of the constituent to the total peak area. A flame ionization detector's advantage changes in flow rate have little effect on the detector's response [28]. Fatty acid analysis in oils using GC has been carried out $[22,23,25$, 26, 29-33].

Stearic acid or stearate as SFA in seeds and nuts helps in eliminating the potential cardiovascular disease. Also, unsaturated fatty acids linolenate, linoleate, and oleate are good for health. Therefore, researchers have an interest in the evaluation of fatty acids in seeds and nuts using spectroscopy and chromatography. The present study's objectives are (a) optimization of oil extraction method (b) identification of fatty acids in seeds and nuts using ATR, NMR, and GC-FID. It is hoped that the study provides useful information on sources of beneficial fatty acid methyl esters, especially stearate in seeds and nuts.

\section{Materials and Methods}

Seeds and nuts (candlenut, peanut, sacha inchi, sesame, sunflower) were collected from Taiwan. Chemicals and equipment used were n-hexane high grade (CAS 110543), acetone (CAS 67-64-1), methanol 99.5\% (Merck), sodium hydroxide (CAS 1310732), sodium chloride (CAS 764145), hydrochloric acid (CAS 110563), distilled water. d-chloroform (865496), tetramethylsilane (TMS) 99.9\% (CIL), distilled water, drying oven (DOS45), Soxtec ${ }^{\mathrm{TM}}$ 8000 extraction unit (FOSS), analytical balance (AND GR-200), moisture analyzer (AND MX-50 JASCO), ATR model PRO450-S, NMR Bruker AVANCE $500 \mathrm{MHz}$, GC-FID (Agilent Technologies 7890B), CP-Sil 88 column $100 \mathrm{~m}$ diameter $0.25 \mathrm{~mm}$, temperature limits $50^{\circ} \mathrm{C}$ $225^{0} \mathrm{C}$.

\section{1) Oil extraction procedure}

The sample was made into flour and then dried at $50^{\circ} \mathrm{C}$ until constant weight. Also, the effect of drying time on moisture values was carried out. The time variation range used was $0-96$ hours. The samples were stored in a closed glass bottle at room temperature until use.

Sample $(3 \mathrm{~g})$ was weighed and transferred into a cellulose cup and then kept into the Soxtec. The aluminum cup was weighed, filled with $50 \mathrm{~mL}$-hexane, and then kept into the Soxtec. The extraction was carried out at $135^{\circ} \mathrm{C}$, boiling time $40 \mathrm{~min}$, condensation for $60 \mathrm{~min}$, and a recovery time of $15 \mathrm{~min}$. After completion of the extraction, the machine automatically shuts down. The aluminum cup was heated at $80^{\circ} \mathrm{C}$ for $60 \mathrm{~min}$ to evaporate the solvent. The cup was allowed to cool down at room temperature and weighed. The oil extract weight was obtained from the difference between the initial weight and the aluminum cup's final weight. The percentage of oil extract was obtained from the extract's weight divided by the sample's total weight. This research also investigated temperature, sample weight, solvent volume, and boiling time. The temperature variations used were $100-145^{\circ} \mathrm{C}$, weight $1-6 \mathrm{~g}$, solvent volume $40-90 \mathrm{~mL}$, and boiling time 20-80 minutes.

\section{2) Attenuated Total Reflection (ATR) procedure}

For a liquid sample, 1 drop of oil was applied onto the prism measuring surface. Turned the handle counterclockwise to raise the pressure head and contact with the prism. Set the wavenumber to $400-4000 \mathrm{~cm}^{-1}$. The prism was properly cleaned. The prism crystals' surface was cleaned with acetone and then waited for 10-15 min. The same steps were carried out for the flour samples.

\section{3) Nuclear Magnetic Resonance (NMR) procedure}

A total of $100 \mu \mathrm{L}$ of oil sample was taken into the 
NMR sample tube, then $600 \mu \mathrm{L}$ of d-chloroform was added and then homogenized for 5 minutes. After that, 1 drop of TMS was added using a dropper, then the sample was homogenized again. The NMR sample tube was closed tightly and then inserted into the NMR machine. Before shimming, the temperature was set to $298 \mathrm{~K}$. The shimming process of NMR spectra was carried out to get symmetrical NMR peaks.

\section{4) Gas Chromatography - Flames Ionization Detector (GC-FID) Procedure}

The sample was prepared by saponification and esterification. Oil $(0.05 \mathrm{~g})$ was mixed with $1 \mathrm{~mL}$ $\mathrm{n}$-Hexane. The mixture $(1 \mathrm{~mL})$ was taken and added with $1 \mathrm{~mL}$ of $1 \mathrm{~N} \mathrm{NaOH}$ in methanol. Saponification was carried out at $80^{\circ} \mathrm{C}$ for $1 \mathrm{~h}$ and then proceeded with the esterification process at $75^{\circ} \mathrm{C}$ for $2 \mathrm{~h}$ using $1 \mathrm{~mL}$ of $3 \mathrm{~N}$ $\mathrm{HCl}$ in methanol. After completion of the esterification, 6 $\mathrm{mL}$ of saturated sodium was added to the mixture, centrifuged until it separated into two layers. After that, the organic layer was taken, and then $1 \mathrm{~mL}$ of n-hexane was added. It was filtered then analyzed with a GC-FID machine. The chromatography tube was set at an initial temperature of $130^{\circ} \mathrm{C}$, heating speed of $1^{\circ} \mathrm{C} / \mathrm{min}$. The final temperature was set to $200^{\circ} \mathrm{C}$ for $60 \mathrm{~min}$. Front inlet mode was set to $28 \mathrm{psi}, 250{ }^{\circ} \mathrm{C}$, split ratio 50 : 1 , mobile phase was Helium, split-flow $33.3 \mathrm{~mL} / \mathrm{min}$.

\section{Results and Discussion}

\section{1) Oil extraction}

The intrinsic quality and distribution period of a food ingredient depends on the moisture content. Excess moisture can cause mold growth quickly to spoil the food. The market allows a maximum of $10 \%$ moisture in walnut $[34,35]$. Most seeds and nuts are processed by roasting to release oil in the cells, thus facilitating oil extraction [16]. The drying process with different methods has been reported by Nejad [36]. This process does not significantly affect free fatty acids in pistachio nuts.

In our study, a drying temperature of $50^{\circ} \mathrm{C}$ and a duration of 48-72 $\mathrm{h}$ have resulted in the lowest moisture percentages in five seeds and nuts (Fig. 1). According to Najad [36], products dried at low temperatures have good storage stability. Drying at a temperature of $30-70^{\circ} \mathrm{C}$ can reduce the activity of the enzymes in nuts. Drying for a shorter duration is better because it does not change the color of the product. Ajibola [37] has reported that with increasing moisture, the porosity can increase. The change in percent of moisture after drying in each sample was $6.1 \%$ to $2.42 \%$ (sunflower), $5.39 \%$ to $2.42 \%$ (peanut); $5.19 \%-2.76 \%$ (sacha inchi), $3.86 \%$ to $1.77 \%$ (candlenut), and $1.92 \%$ to $1.56 \%$ (sesame) (Fig. 2). The percentage of moisture safe for storing peanuts is $6-8 \%[38,39]$. According to the report, high percentages of oil extracts can be obtained at low moisture levels. At high moisture, the obtained oil content is low [39].

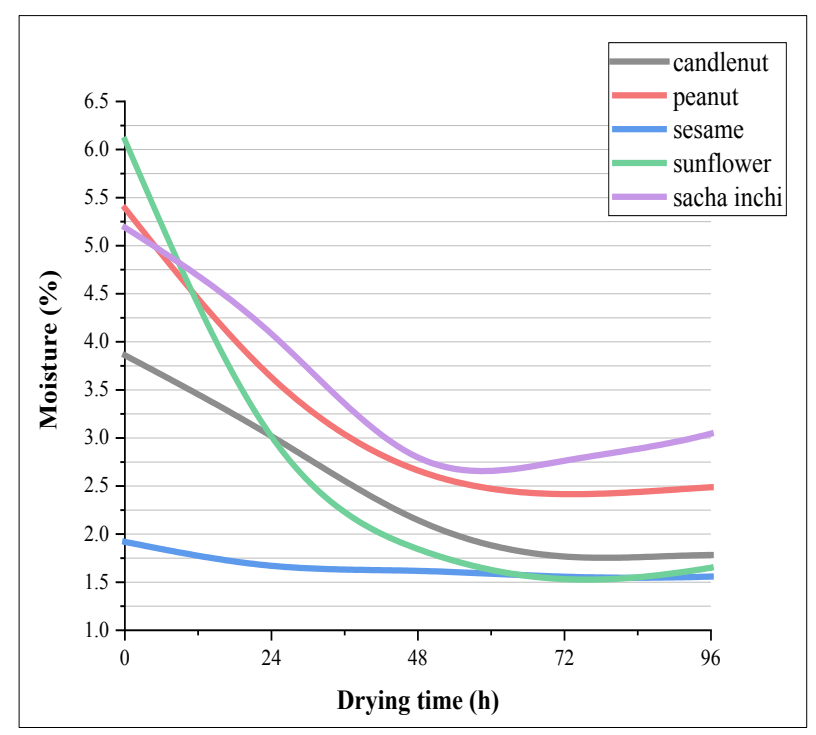

Figure 1. Percent of moisture in different samples

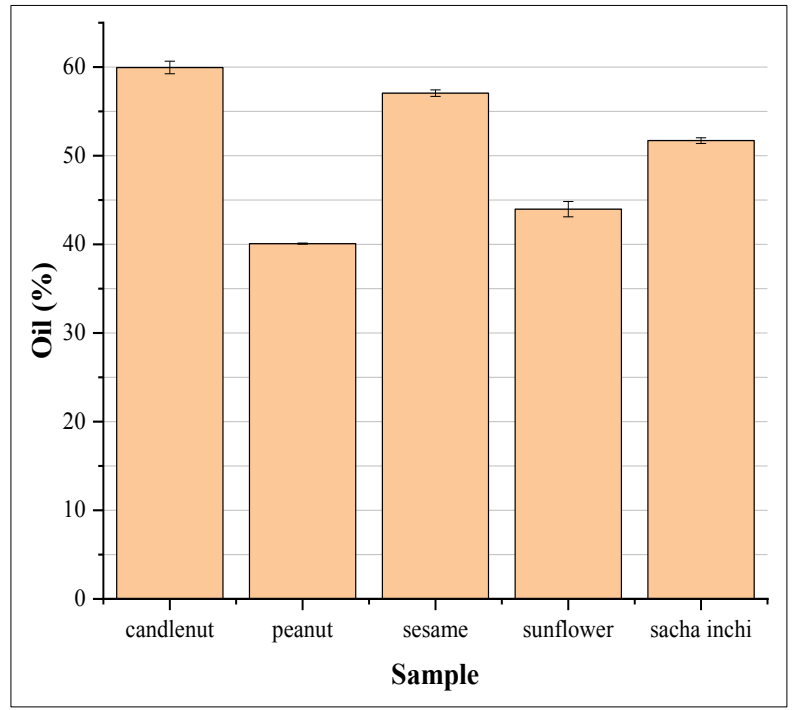

Figure 2. Percentages of oil in different samples

In the present study, oil extraction was carried out by the Soxtec $8000^{\mathrm{TM}}$. Compared with the Soxhlet, Soxtec $8000^{\mathrm{TM}}$ has a short time for the extraction process, and the solvent recovery is automatic. While the maximum weight of the sample is $15 \mathrm{~g}$. Some parameters that need to be optimized during the extraction by Soxtec are temperature, sample weight, type of solvent, solid-liquid ratio, and extraction time [40]. The optimum extraction conditions using Soxtec and n-hexane were: solvent volume $50 \mathrm{~mL}$, boiling time $40 \mathrm{~min}$, temperature $135^{\circ} \mathrm{C}$. the oil percentages in five seeds and nuts were: candlenut 
(59.95\%), peanut $(40.08 \%)$, sesame $(57.06 \%)$, sunflower (43.97\%), sacha inchi (51.71\%) (Fig. 2).

Several researchers have used hexane as a solvent in the Soxhlet method [10, 41, 42]. The different solvents (n-hexane, ethyl acetate, petroleum ether, acetone) showed different chemical characteristics, affecting the potential nutritional value of oil. Extraction by n-hexane had higher monounsaturated fatty acid (C18:1) and lower polyunsaturated fatty acids (C18:2) [43]. Extraction by hexane solvent at cold temperature conditions produced oil extracts rich in linolenate [44].

\section{2) ATR analysis}

Seeds and nuts are common sources of protein. Besides, flour also contains carbohydrates, oil, minerals, and water. Functional groups found in candlenut, peanut, sesame, sunflower, and sacha inchi flours included amino groups, carboxyl groups, hydroxyl groups, carbonyl groups (aldehydes or ketones), esters, alkanes, and alkenes. IR spectra in Fig. 3 show the vibrational frequency of the molecules. The stronger the vibration, the higher is the absorbance value, which means a high concentration of these molecules in the sample.

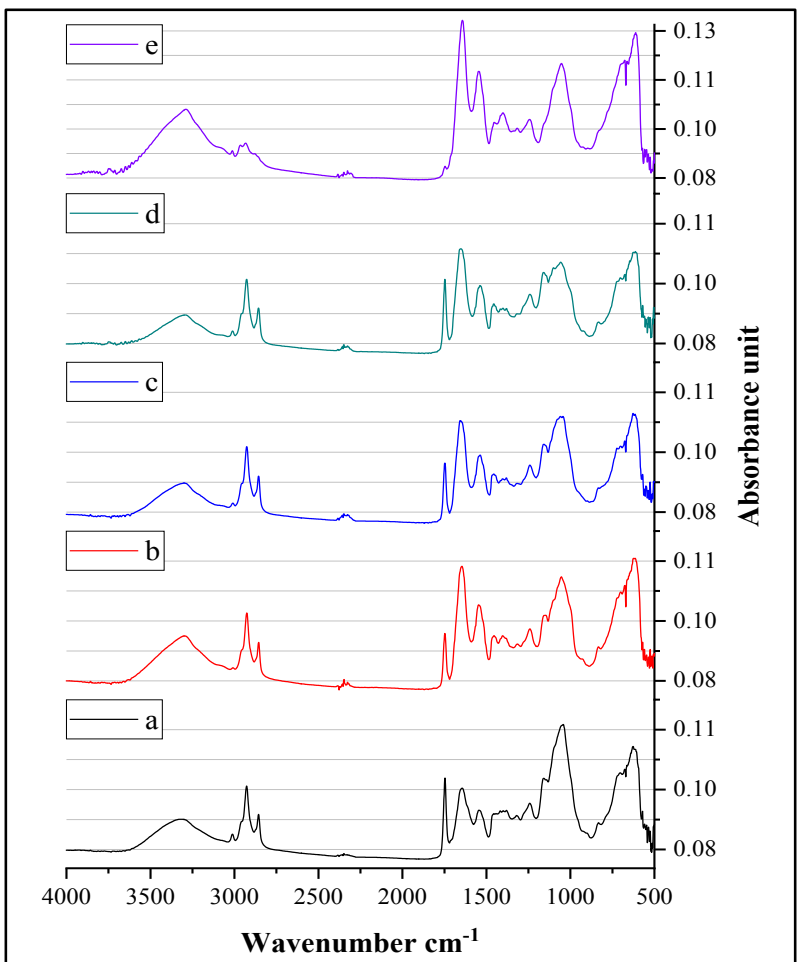

Figure 3. ATR spectra of candlenut flour (a), peanut flour (b), sesame flour (c), sunflower flour (d), and sacha inchi flour (e)

Table 1. IR spectra interpretation of candlenut flour (a), peanut flour (b), sesame flour (c), sunflower flour (d), and sacha inchi flour (e).

\begin{tabular}{|c|c|c|c|c|c|c|}
\hline \multirow{2}{*}{ Bond } & \multicolumn{6}{|c|}{ Wavenumber $\left(\mathrm{cm}^{-1}\right)$} \\
\hline & Reference [21] & $\mathbf{a}$ & b & c & d & e \\
\hline $\mathrm{N}-\mathrm{H}$ & $3300-3500$ & 3320 & 3283 & 3295 & 3301 & 3283 \\
\hline $\mathrm{C}-\mathrm{N}$ & $1180-1360$ & 1239 & 1239 & 1238 & 1237 & 1237 \\
\hline & $3010-3095$ & 3011 & & & & 3013 \\
\hline$I_{C}$ & $1500-1600$ & 1538 & 1544 & 1536 & 1533 & 1541 \\
\hline & $675-995$ & 627 & 624 & 627 & 613 & 612 \\
\hline $\mathrm{C}-\mathrm{H}$ & $2850-2970$ & 2929 & 2927 & 2927 & 2927 & 2933 \\
\hline & $1610-1680$ & 1651 & 1645 & 1660 & 1651 & 1641 \\
\hline $\mathrm{C}-\mathrm{O}$ & $1050-1300$ & 1043 & 1053 & 1053 & 1058 & 1057 \\
\hline $\mathrm{C}=\mathrm{O}$ & $1690-1760$ & 1748 & 1748 & 1748 & 1748 & \\
\hline $\mathrm{O}-\mathrm{H}$ & $2500-3650$ & 3320 & 3283 & 3295 & 3301 & 3283 \\
\hline
\end{tabular}




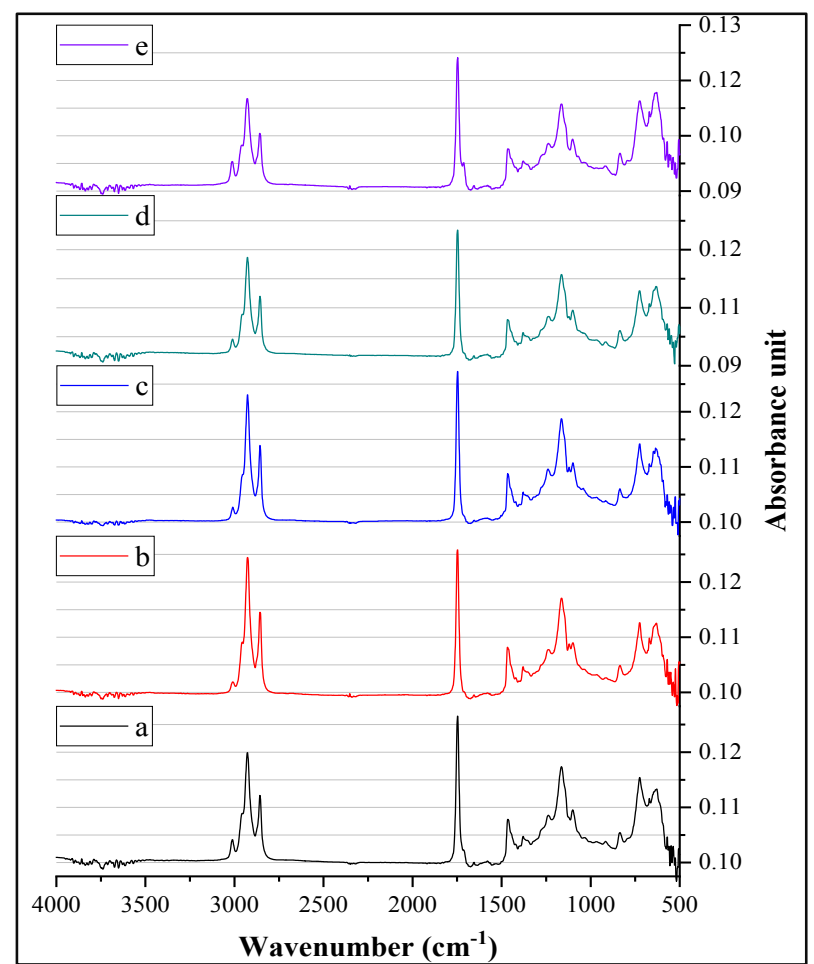

Figure 4A. ATR spectra of oil in candlenut (a), peanut (b), sesame (c), sunflower (d), and sacha inchi (e)

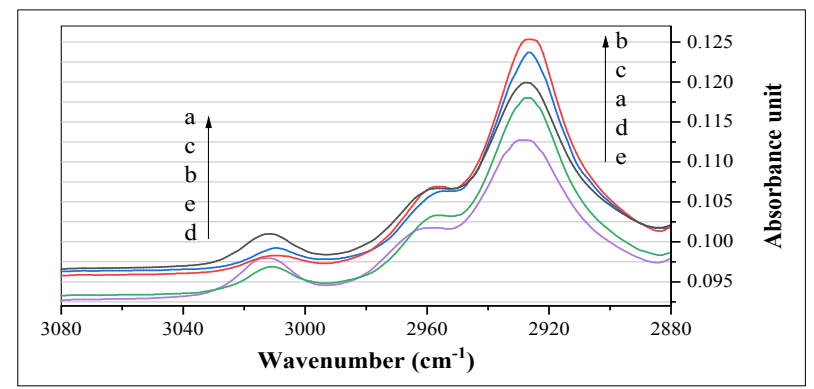

Figure 4B. ATR spectra of oil expand $2880-3050 \mathrm{~cm}^{-1}$ (B) in candlenut (a), peanut (b), sesame (c), sunflower (d), and sacha inchi (e)
The IR spectra of flour (Fig. 3) and oil (Fig. 4) have a difference in the wavenumber of $3400 \mathrm{~cm}^{-1}$, indicating that the vibrational frequency of $\mathrm{O}-\mathrm{H}$ molecules in oil is less than the flour. The extraction process using temperature above the boiling point of water may cause weak vibrations of $\mathrm{O}-\mathrm{H}$ molecules in the oil. $\mathrm{O}-\mathrm{H}$ vibrational frequency overlaps with $\mathrm{N}-\mathrm{H}$ vibrational frequency in flour, allowing denaturation of the protein during oil extraction. Heating at a temperature above $60^{\circ} \mathrm{C}$ caused denaturation of proteins. Many peaks overlapped at wavenumbers around $1200 \mathrm{~cm}^{-1}$ (Figure 3 and Table 1). It is due to single bond vibrations which have almost the same energy [28], such as $\mathrm{C}-\mathrm{N}\left(1180-1360 \mathrm{~cm}^{-1}\right), \mathrm{C}-\mathrm{H}$ $\left(1340-1470 \mathrm{~cm}^{-1}\right), \mathrm{C}-\mathrm{O}\left(1050-1300 \mathrm{~cm}^{-1}\right)$.

Oil is a mixture of glycerol and triglycerides composed of alkane, alkenes, and esters functional groups. IR spectra of oil are presented in Fig. 4A and the interpretation in Table 2. Sacha inchi oil has strong peaks in $3016 \mathrm{~cm}^{-1}$ (stretching vibration $\mathrm{C}=\mathrm{C}$ ), $2925 \mathrm{~cm}^{-1}$, and $2855 \mathrm{~cm}^{-1}$ (stretching vibrations overlapping with $\mathrm{C}-\mathrm{H}$ methylene group vibrations). The high absorbance value indicates that the oil is rich in polyunsaturated fatty acids [23]. The frequency of molecular vibrations at the wavenumber between $3009-3006 \mathrm{~cm}^{-1}$ occurred in non-oxidized oil (Fig. 4B). The peak at $3009 \mathrm{~cm}^{-1}$ is the vibration stretching of a cis double bond. The higher the oil concentration, the higher the peak height was [45]. Based on this, the strong vibrations of unsaturated fatty acids were found in candlenut, sesame, peanut, sacha inchi, and sunflower, respectively. The peak at $2952 \mathrm{~cm}^{-1}$ is vibrations of the aliphatic group attached to $=\mathrm{CH}$, and the stronger vibration of that molecule was present in peanut, sesame candlenut, sunflower, and sacha inchi, respectively. The difference in vibrations' strength indicates a different type of unsaturated fatty acids in the sample.

Table 2. IR spectra interpretation of oil in candlenut (a), peanut (b), sesame (c), sunflower (d), and sacha inchi (e)

\begin{tabular}{|c|c|c|c|c|c|c|}
\hline \multirow{2}{*}{ Bond } & \multicolumn{6}{|c|}{ Wavenumber $\left(\mathrm{cm}^{-1}\right)$} \\
\hline & Reference [43] & $\mathbf{a}$ & b & c & d & $\mathbf{e}$ \\
\hline \multirow{3}{*}{${ }_{\mathrm{C}=\mathrm{C}^{\prime}}^{\mathrm{H}}$} & 3010 & 3008 & 3000 & 3010 & 3012 & 3016 \\
\hline & 1653 & 1652 & 1653 & 1649 & 1659 & 1659 \\
\hline & $995-675$ & $\begin{array}{c}911 \\
837 \\
721 \\
633 \\
\end{array}$ & $\begin{array}{l}834 \\
727 \\
630\end{array}$ & $\begin{array}{l}835 \\
726 \\
633\end{array}$ & $\begin{array}{l}914 \\
833 \\
722 \\
629 \\
\end{array}$ & $\begin{array}{l}913 \\
833 \\
722 \\
635 \\
\end{array}$ \\
\hline \multirow{4}{*}{$\mathrm{C}-\mathrm{H}$} & 2927 & 2929 & 2929 & 2925 & 2925 & 2925 \\
\hline & 2885 & 2859 & 2859 & 2857 & 2855 & 2855 \\
\hline & 1461 & 1466 & 1463 & 1461 & 1464 & 1467 \\
\hline & 1376 & 1378 & 1377 & 1377 & 1377 & 1376 \\
\hline $\mathrm{C}=\mathrm{O}$ & 1746 & 1744 & 1750 & 1747 & 1746 & 1749 \\
\hline \multirow{4}{*}{$\mathrm{C}-\mathrm{O}$} & 1238 & 1239 & 1242 & 1237 & 1242 & 1237 \\
\hline & 1163 & 1165 & 1165 & 1166 & 1161 & 1168 \\
\hline & $1118-1120$ & & 1116 & 1123 & & \\
\hline & 1100 & 1104 & 1096 & 1102 & 1101 & 1099 \\
\hline
\end{tabular}


The ester molecule's strong stretching vibration was also observed at wavenumber $1168 \mathrm{~cm}^{-1}$, indicating that the oil is rich in unsaturated fatty acids. The peak at 1749 $\mathrm{cm}^{-1}$ is a stretching vibration of the triglyceride molecule. Aliphatic functional groups that overlap with aryl were detected at wavenumber $1467 \mathrm{~cm}^{-1}$. Based on the trend of peaks in all samples, it can be seen that all samples contain MUFAs and PUFAs. Overlapping of peaks has been reported earlier. The vibration of the methylene group $\left(\mathrm{CH}_{2}\right)$ overlaps with cis-alkene $($ cis- $\mathrm{HC}=\mathrm{CH})$, the stretching vibration ester $(\mathrm{C}-\mathrm{O})$, the bending vibration $\mathrm{C}-\mathrm{H}$, the stretching vibration ester $(\mathrm{C}=\mathrm{O})$, and hydroxyl group $(\mathrm{OH})[24]$.

\section{3) NMR analysis}

NMR analysis was carried out on oils according to the methylene group both on $\alpha-\mathrm{CH}_{2}$ attached to and $\mathrm{CH}_{2}$ as the long chain of fatty acids. NMR spectra in all samples showed different peaks but had a similar pattern. It indicates all samples have a similar functional group. (Fig $5)$. Unsaturated fatty acids methyl ester such as oleate $(\omega-9)$, linoleate $(\omega-6)$, and other acyl groups exist in a chemical shift of $0.83-0.93$ ppm. $\omega-6$ on sacha inchi appears at $0.889 \mathrm{ppm}, \omega-9$ appears at 0.879 on linseed oil, while $\omega-3$ was detected at $0.94-1 \mathrm{ppm}$ [23]. $\omega-3$ appears at $2.07 \mathrm{ppm}$ (multiplet), $\omega-6$ at $2.3 \mathrm{ppm}$ (multiplet), $\omega-9$ at $2.01 \mathrm{ppm}$ (multiplet) [46]. Based on the data in Table 3 and Fig. 5, $\omega-3$ was found in sacha inchi and candlenut, while $\omega-6$ and $\omega-9$ were found in all samples. In this experiment, candlenut and sacha inchi contained $\omega-3$ because both had chemical shifts at $2.80 \mathrm{ppm}$ (proton identities in $\mathrm{C} 11$ and $\mathrm{C} 14$ as a structure of linolenate). $\omega-3$ was also found by Guillén [23] in sacha inchi oil. The NMR results were correlated with the detection of molecular vibrations in IR, which inform at peak 3010, $2927,2889,1168 \mathrm{~cm}^{-1}$ as PUFAs and MUFAs.

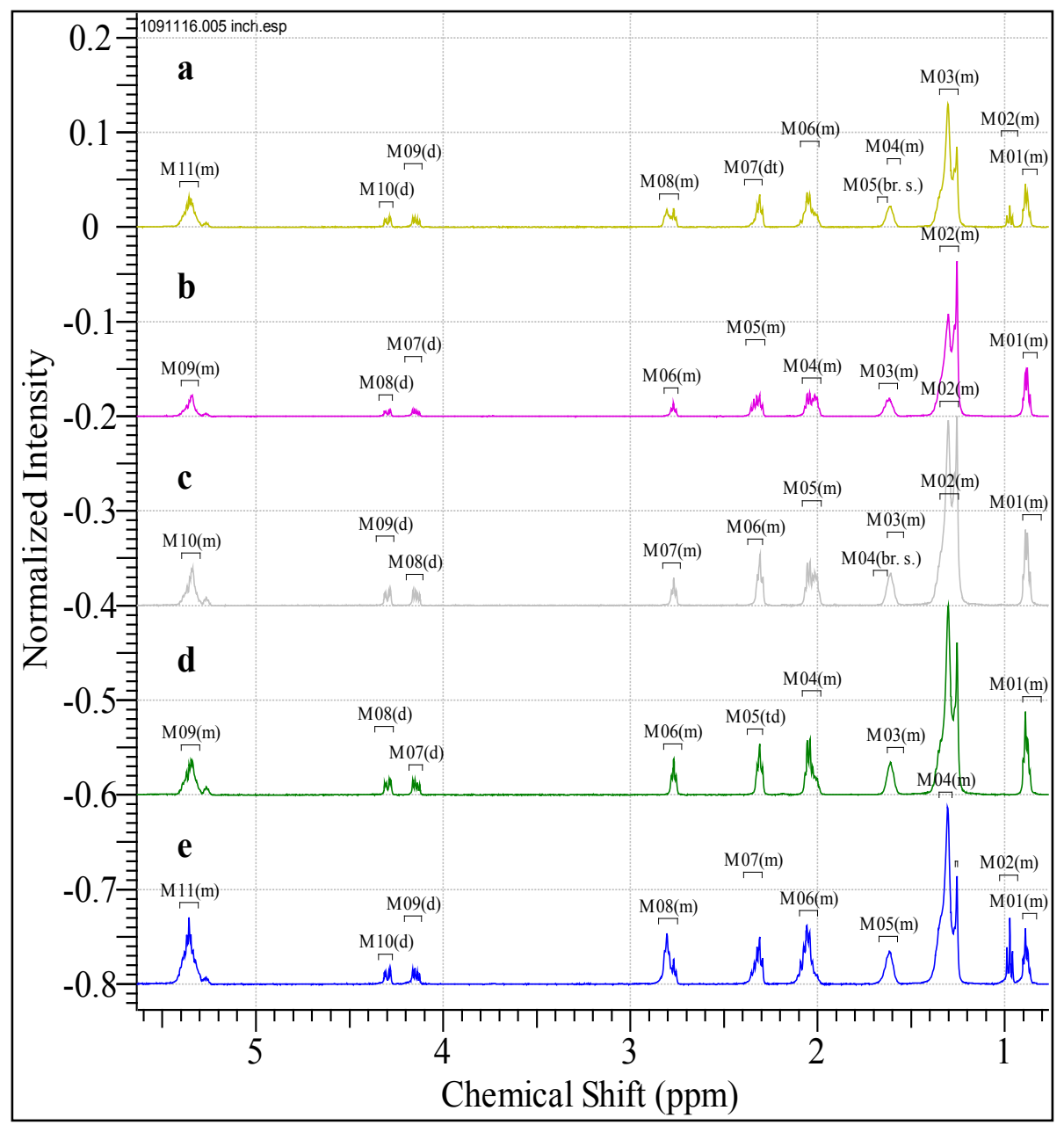

nd: M01: Multiplets 01; s (singlet); br.s (broadened singlet); d (doublet); dt (double triplet); m (multiplet)

Figure 5. ${ }^{1} \mathrm{H}$ NMR of oil in candlenut (a), peanut (b), sesame (c), sunflower (d), and sacha inchi (e). 
Table 3. Identification of $\omega-3, \omega-6, \omega-9$ and SFA in Candlenut (a), Peanut (b), Sesame (c), Sunflower (d), and Sacha Inchi (e)

\begin{tabular}{|c|c|c|c|c|c|}
\hline \multirow{2}{*}{ Functional Group } & \multicolumn{5}{|c|}{ Chemical shift (ppm) } \\
\hline & $\mathbf{a}$ & b & c & d & $\mathbf{e}$ \\
\hline \multirow{2}{*}{$\omega-6$ acyl } & 0.880 & 0.880 & 0.879 & 0.879 & 0.879 \\
\hline & 2.03 & 2.03 & 2.03 & 2.03 & 2.04 \\
\hline$\omega-9$ acyl & 0.890 & 0.891 & 0.890 & 0.890 & 0.890 \\
\hline \multirow{2}{*}{$\omega-3$ acyl } & 0.975 & nd & nd & nd & 0.975 \\
\hline & 2.06 & nd & nd & nd & 2.07 \\
\hline Methyl Saturated & 1.256 & 1.256 & 1.256 & 1.256 & 1.256 \\
\hline Methyl Unsaturated & $\begin{array}{c}1.305 \\
2.02\end{array}$ & $\begin{array}{c}1.303 \\
2.02\end{array}$ & $\begin{array}{c}1.303 \\
2.02\end{array}$ & $\begin{array}{c}1.303 \\
2.02\end{array}$ & $\begin{array}{c}1.303 \\
\text { nd }\end{array}$ \\
\hline
\end{tabular}

The proportion of protons in the fatty acid chain can be observed. For example, 28 protons contribute to the methylene group of $\mathrm{C} 22: 1$ at a chemical shift of 1.2-1.4 ppm [47]. The height intensity of the peak at chemical shift $1.2-1.4 \mathrm{ppm}$ belongs to the proton signal of the methylene group. Chemical shift $1.2 \mathrm{ppm}$ belongs to methylene saturated while $1.3 \mathrm{ppm}$ belongs to methylene unsaturated. The proportion of methylene saturated in candlenut (0.65), sunflower (0.81), and sacha inchi (0.60) was lower than methylene unsaturated. Sesame (1.02) has balanced proportions, and peanut has more proportion of SFA (1.52). The peak at 0.98 belongs to the $\omega-3$ acyl group. The height of the $\omega-3$ acyl group was equal to the $\omega-9$ acyl group and $\omega-6$ acyl group on sacha inchi. The proportion of $\omega-3$ acyl group in the candlenut was less than $\omega-9$ acyl group and $\omega-6$ acyl group. The GC results in Table 4 support NMR data, sacha inchi rich in linolenate. The types of saturated fatty acids in vegetable oil were palmitate and stearate. Both of them did not have proton signals at chemical shifts of 5.36, 2.78, $2.03 \mathrm{ppm}$. This chemical shift was owned by protons in the functional groups $=\mathrm{CH} \quad$ (Olefinic), $=\mathrm{CH}-\mathrm{CH}-\mathrm{CH}=$ (allylic), $=\mathrm{CH}-\mathrm{CH}_{2}$ (bis-allylic) [46-48]. Based on this, palmitate and stearate as SFAs were detected in all samples, including candlenut, peanut, sesame, sunflower, and sacha inchi. The $\omega-3$ acyl group, $\omega-6$ acyl group, $\omega-9$ acyl group, and SFA have a functional group and chemical shift: $-\mathrm{CH}_{2} \mathrm{COOH} \quad(2.35-2.36 \quad \mathrm{ppm}), \quad-\mathrm{CH}_{2} \mathrm{CH}_{2} \mathrm{COOH}$ (1,61-1.64 ppm), $-\mathrm{CH}_{2}$ (1.24-1.35 ppm) and $-\mathrm{CH}_{3}$ (0.88-0.98 ppm). Different types of fatty acid containing the same functional group can cause peak overlap on the same chemical shift.

\section{4) GC-FID analysis}

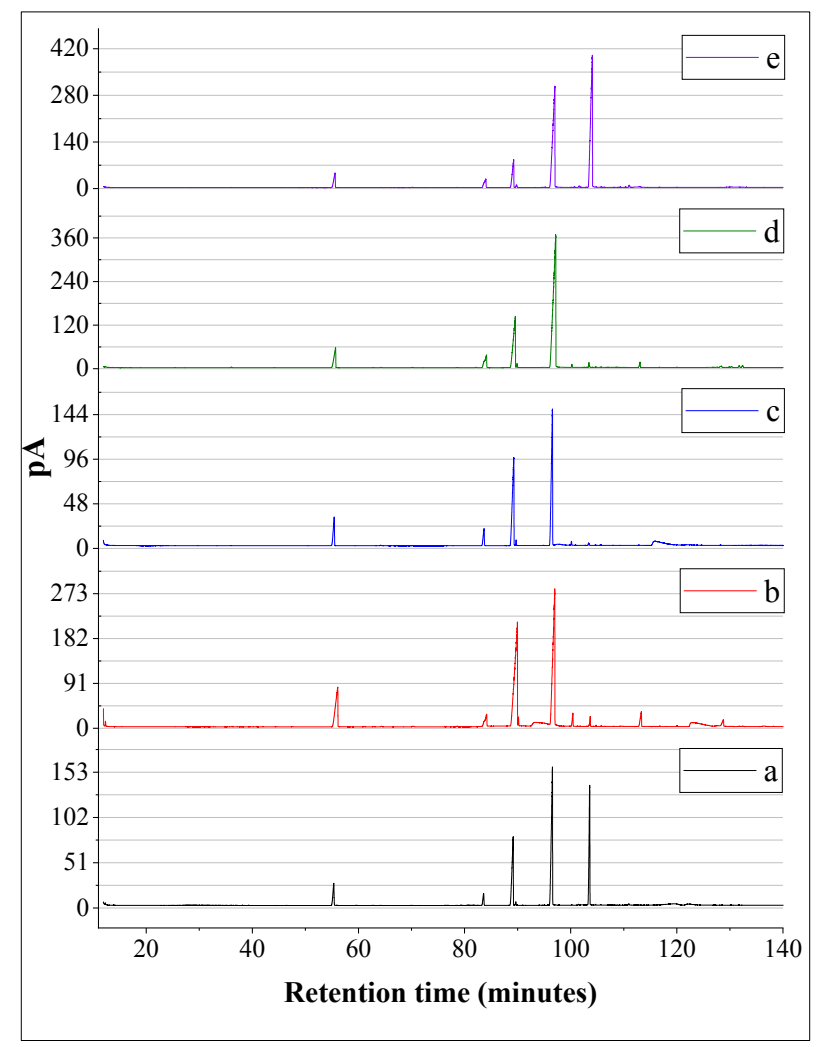

Figure 6. GC-FID chromatogram of oil in candlenut (a), peanut (b), sesame (c), sunflower (d), and sacha inchi (e). 
Table 4. Identification of fatty acid in candlenut (a), peanut (b), sesame (c), sunflower (d), and sacha inchi (e).

\begin{tabular}{ccccccc}
\hline $\begin{array}{c}\text { Fatty acid } \\
\text { methyl ester (FAME) }\end{array}$ & & a (\%) & b (\%) & c (\%) & d (\%) & e (\%) \\
\hline Methyl Butyrate & C14:0 & nd & 0.16 & nd & nd & nd \\
Methyl Palmitate & C16:0 & 3.79 & 7.01 & 5.40 & 5.26 & 2.15 \\
Methyl Stearate & C18:0 & 1.81 & 0.71 & 2.96 & 4.02 & 1.52 \\
Methyl Arachidate & C20:0 & nd & 0.80 & 0.32 & 0.26 & nd \\
Methyl Behenate & C22:0 & nd & 1.43 & nd & 0.71 & 0.20 \\
Methyl Oleate & C18:1 & 13.67 & 9.39 & 21.87 & 16.79 & 4.17 \\
Methyl Eicosenoate & C20:1 & 14.78 & 0.37 & & 0.48 & nd \\
Methyl Linoleate & C18:2 & 25.69 & 20.15 & 26.38 & 16.12 & 20.74 \\
Methyl Linolenate & C18:3 & nd & nd & nd & nd & 22.88 \\
Total & SFA & 5.59 & 10.11 & 8.68 & 10.25 & 3.87 \\
\hline
\end{tabular}

nd: not detected; SFA: saturated fatty acid; MUFA monounsaturated fatty acid; PUFA: polyunsaturated fatty acid

GC-FID analysis shows that each sample has various types of fatty acid methyl esters (Fig. 6, Table 4). There are five types of fatty acid methyl esters in candlenut: linoleate, eicosenoate, oleate, palmitate, and stearate. Peanut has eight types of fatty acid methyl esters such as linoleate, oleate, palmitate, behenate, arachidonate, stearate, eicosenoate, butyrate. Sesame has five types of fatty acid methyl esters: linoleate, oleate, palmitate, stearate, and arachidonate. Sunflower has seven types of fatty acid methyl esters: oleate, linoleate, palmitate, stearate, behenate, eicosenoate, arachidonate. Sacha inchi has six types of fatty acid methyl esters: linolenate, linoleate, oleate, palmitate, stearate, behenate. Only $0.157 \%$ butyrates were found in peanuts. Peanuts have been reported to contain butyrate as much as $127 \mathrm{mg} / \mathrm{g}$ [1]. Most SFAs were found in sunflower with palmitate and stearate. Most MUFAs were found in candlenut with the types of eicosenoate and oleic. Most PUFAs were found in sacha inchi with linolenate and linoleate. Only sacha inchi has linolenate as much as $22.88 \%$. Some researchers have found linolenate in sacha inchi as much as $36 \%$ [49], $44 \%$ [30], and 50.8\% [50]. Based on the NMR results, candlenut also contains linolenate, but it is not detected in the GC results. Linoleate and linolenate are PUFAs. These have the same functional group that caused the proton signal detection overlap. Linolenate is a fatty acid methyl ester that causes an oxidation reaction very quickly compared with stearate. The high levels of PUFAs and MUFAs in oil can cause an oxidative reaction, especially at high temperatures [51]. The double bond is sensitive to oxidation reaction, as the electrons become stronger, attracting protons around them [52]. Peanut has a peak in retention time of $89.3 ; 89.5 ; 89.7 ; 89.8 ; 89.9 ; 89.9$ min. The retention time is identical to that of oleate. The SFAs type in peanuts was more varied than in other samples. This supports the NMR data, showing that the proportion of SFAs proton signals is more than unsaturated at 1.2 $1.3 \mathrm{ppm}$

\section{Conclusions}

Extraction conditions like Soxtec $8000^{\mathrm{TM}}$ at $135^{\circ} \mathrm{C}$, n-hexane $50 \mathrm{~mL}$, boiling time $40 \mathrm{~min}$, total extraction time $115 \mathrm{~min}$, sample weight $3 \mathrm{~g}$ resulted in different oil percentages in different seeds and nuts, e.g., candlenut (59.95\%), peanut $(40.08 \%)$, sesame $(57.06 \%)$, sunflower (43.97\%), and sacha inchi (51.71\%). The IR spectra of oil and flour showed different peaks of the $\mathrm{OH}$ bond at 3400 $\mathrm{cm}^{-1}$. The peak was stronger in flour compared to oil. Many peaks overlapped in the wavenumber around 1200 $\mathrm{cm}^{-1}$. NMR results show that the chemical composition of the oil is diverse. Linolenate has a chemical shift of 0.975 ppm and was only found in candlenut and Sacha inch oils. The ATR, NMR, and GC-FID results showed that all samples contained unsaturated fatty acid. PUFAs and MUFAs were mostly found in candlenut, followed by sesame, sacha inchi, sunflower, and peanut. The types of fatty acid methyl esters varied among five different seeds and nuts, e.g., candlenut has five types of fatty acid methyl esters, while peanut has eight types, sesame five types, sunflower seven types, and six types in sacha inchi. Candlenut, peanut, sesame, and sacha inchi were rich in linoleate $(\omega-6)$ as much as $25.68 \%, 20.15 \%, 26.38 \%$, and $20.73 \%$, respectively. Oleate $(\omega-9)$ was abundant in sesame $(21.87 \%)$ and sunflower (16.78\%). Linolenate ( $\omega-6)(22.88 \%)$ was found only in sacha inchi. The maximum percent of the stearate was found in sunflower $(4.02 \%)$ followed by sesame $(2.96 \%)$, candlenut $(1.81 \%)$, sacha inchi $(1.52 \%)$, and peanut $(0.71 \%)$. The area percentage ratio calculation showed that the largest area of the SFAs area was sesame. The MUFAs were mainly 
found in candlenut, while the sacha inchi mostly have PUFAs.

\section{Acknowledgments}

The authors thank the support of the Department of Applied Chemistry, Chaoyang University of Technology, Taiwan, and West Nusa Tenggara Provincial Government, Indonesia.

\section{Competing Interests}

Authors have no competing financial, professional, or personal interests that might have influenced the performance or presentation of the work described in this manuscript.

\section{Authors' Contributions}

SY and WJC conceived the research idea. SY, DSS, LHY, and CYC collected the data, developed the theory, verified and analyzed the data. SY prepared the manuscript draft. WJC supervised the research work. DCA made a substantial contribution to the revision of the manuscript. All authors discussed the results and contributed to the final manuscript.

\section{Author Detail}

SY, DSS Senior Ph.D. Student, LHY technical supervisor in Asia Mycotoxin Analysis Center, CYC Master Student, DCA, and WJC are Professors in Chaoyang University of Technology, Taiwan

\section{REFERENCES}

[1] Øvrebø, T, "Identification and quantification of fatty acids in nut oils by GC-MS," Master Thesis, Faculty of Chemistry, Biotechnology and Food Science Identification, Norwegian University of Life Sciences pp.1-80, 2019. https://nmbu.brage.unit.no/

[2] Nengroo, Z. R., \& Rauf, A, "Fatty acid composition and antioxidant activities of five medicinal plants from Kashmir," Industrial Crops and Products, vol. 140, issue August, pp. 111596, 2019, DOI: 10.1016/j.indcrop.2019.111596

[3] Hazrati, S., Nicola, S., Khurizadeh, S., Alirezalu, A., \& Mohammadi, H, "Physico-chemical properties and fatty acid composition of Chrozophora tinctoria seeds as a new oil source," Grasas y Aceites, vol. 70, no. 4. 2019, DOI: 10.3989/gya.0939182
[4] Pattanayak, S, "Trans-fats of processed and fried foods - A choice for taste or serious health problems?" Exploratory Animal and Medical Research, vol.9, no.1, pp.5-14, 2019. ISSN 2319-247X

[5] Idris, A. A., Nour, A. H. A. H., Ali, M. M., Erwa, I. Y., Omer Ishag, O. A., \& Nour, A. H, "Physicochemical Properties and Fatty Acid Composition of Ocimum basilicum L. Seed Oil," Asian Journal of Physical and Chemical Sciences, vol.8, no.1, pp.1-12, 2020, DOI: 10.9734/ajopacs/2020/v8i130104

[6] Salas, J. J., Martínez-Force, E., Harwood, J. L., Venegas-Calerón, M., Aznar-Moreno, J. A., Moreno-Pérez, A. J., Garcés, R, "Biochemistry of high stearic sunflower, a new source of saturated fats," Progress in Lipid Research, vol.55, no.1, pp.30-42, 2014, DOI: 10.1016/j.plipres.2014.05.001

[7] Kondamudi, N., \& McDougal, O. M, "Microwave-Assisted Synthesis and Characterization of Stearic Acid Sucrose Ester: A Bio-Based Surfactant, "Journal of Surfactants and Detergents, vol.22, no.4, pp.721-729, 2019, DOI: $10.1002 /$ jsde. 12280

[8] Mortensen, A., Aguilar, F., Crebelli, R., Di Domenico, A., Dusemund, B., Frutos, M. J., ... Lambré, C, "Re evaluation of fatty acids (E 570) as a food additive," EFSA Journal, vol.15, no.5, 2017, DOI: 10.2903/j.efsa.2017.4785

[9] de Figueiredo, A. K., Fernández, M. B., \& Nolasco, S. M, "Extraction of high stearic high oleic sunflower oil (HSHO): Effect of dehulling and hydrothermal pretreatment," Journal of Food Engineering, vol.240, issue January, pp.49-55, 2019, DOI: 10.1016/J.JFOODENG.2018.07.015

[10] Aliyu, M., Atiku Kano, M., Abdullahi, N., Aliyu Kankara, I., Ismail Ibrahim, S., \& Abdullahi Abdulkadir, I, "Extraction, Characterization and Fatty Acids Profiles of Nymphaea Lotus and Nymphaea Pubescens Seed Oils," Biosciences, Biotechnology Research Asia, vol.14, no.4, pp.1299-1307, 2017, DOI: 10.13005/bbra/2573

[11] Ako, H., Kong, N., \& Brown, A, "Fatty acid profiles of kukui nut oils over time and from different sources," Industrial Crops and Products, vol.22, no.2, pp.169-174, 2005, DOI: 10.1016/j.indcrop.2004.07.003

[12] Gaetano, L., \& Grazia, R. (1954), "Chemical composition of the seeds of Aleurites mol," Annali di Chimica (Rome, Italy), vol.44, pp.397-406, 1954, ISSN: 0003-4592

[13] Thakur, V., Paroha, S., \& Mishra, R. P, "Free Fatty Acid Profile of Seven Sesame (Sesamum Indicum L.) Verities," International Journal of Current Microbiology and Applied Sciences, vol.7, no.07, pp.3439-3453, 2018, DOI: 10.20546/ijcmas.2018.707.399

[14] Ali Alsaad, A. J., Altemimi, A. B., Aziz, S. N., \& Lakhssassi, N, "Extraction and Identification of Cactus Opuntia dillenii Seed Oil and its Added Value for Human Health Benefits," Pharmacognosy Journal, vol.11, no.3, pp.579-587, 2019, DOI: 10.5530/pj.2019.11.93

[15] Wang, S., Zhu, F., \& Kakuda, Y. "Sacha inchi (Plukenetia volubilis L.): Nutritional composition, biological activity, and uses," Food Chemistry, vol.265, pp.316-328, 2018, DOI: 10.1016/j.foodchem.2018.05.055

[16] Roy, K., Mukherjee, A., \& Jana, D. K, "Prediction of 
maximum oil yield from almond seed in a chemical industry: A novel type-2 fuzzy logic approach," South African Journal of Chemical Engineering, vol.29, issue July, 2019, pp.1-9, 2019, DOI: 10.1016/j.sajce.2019.03.001

[17] Fernández-Moya, V., Martínez-Force, E., \& Garcés, R, "Temperature effect on a high stearic acid sunflower mutant," Phytochemistry, vol.59, no.1, pp.33-37, 2002, DOI: 10.1016/S0031-9422(01)00406-X

[18] Valenzuela, A., Delplanque, B., \& Tavella, M, "Stearic acid: A possible substitute for trans fatty acids from industrial origin," Grasas y Aceites, vol.62, no.2, pp.131-138, 2011, DOI: $10.3989 /$ gya. 033910

[19] Bassey, I. E., Edward, A. J., \& Robbert, O. O, "Comparative Stability-Reactivity Prediction for Stearic Acid and Linolenic Acid using Density Functional Theory," Journal of Chemical Engineering and Chemistry Research, vol.2, no.1, pp.467-473, 2015 .

[20] Sulistyani, M., \& Huda, N, "Perbandingan Metode Transmisi dan Reflektansi Pada Pengukuran Polistirena Menggunakan Instrumentasi Spektroskopi Fourier Transform Infra Red," Indonesian Journal of Chemical Science, vol.7, no.2, pp.195-198, 2018.

[21] Skoog, D. A., Holler, F. J., \& Crouch, S. R, "Principles of Instrumental Analysis," (L. Olivera, Ed.) (6th ed.). Canada, USA: BROOKS/COLE CENGAGE Learning. 2014

[22] Brühl, L, "Fatty acid alterations in oils and fats during heating and frying, "European Journal of Lipid Science and Technology, vol.116, no.6, pp.707-715, 2014, DOI: 10.1002/ejlt.201300273

[23] Guillén, M. D., Ruiz, A., Cabo, N., Chirinos, R., \& Pascual, G, "Characterization of sacha inchi (Plukenetia volubilis L.) Oil by FTIR spectroscopy and 1H NMR. Comparison with linseed oil," Journal of the American Oil Chemists' Society, vol.80, no.8, pp.755-762, 2003, DOI $10.1007 / \mathrm{s} 11746-003-0768-\mathrm{z}$

[24] Rusli, R., Rosniar, R., Haeruddin, H., \& Nurlansi, N, "Identifikasi Gugus Fungsi Minyak Buah Nipa (Nypa fructicans) Kaliwanggu Teluk Kendari Sulawesi Tenggara," Journal of Tropical Pharmacy And Chemistry, vol.1, no.2, pp.146-152, 2011, DOI: 10.25026/jtpc.v1i2.22

[25] Suri, K., Singh, B., Kaur, A., Yadav, M. P., \& Singh, N, "Impact of infrared and dry air roasting on the oxidative stability, fatty acid composition, Maillard reaction products and other chemical properties of black cumin (Nigella sativa L.) seed oil," Food Chemistry, vol.295, issue April, pp.537-547, 2019, DOI: 10.1016/j.foodchem.2019.05.140

[26] Yilmaz, N., Tuncel, N. B., \& Kocabiyik, H, "Infrared stabilization of rice bran and its effects on $\gamma$-oryzanol content, tocopherols, and fatty acid composition," Journal of the Science of Food and Agriculture, vol.94, no.8, pp.1568-1576, 2014, DOI: 10.1002/jsfa.6459

[27] Hendrawati, T. Y., Nuraini, A., Hakim, R. J., \& Fithriyah, N. $\mathrm{H}$, "Characterization and properties of Gedi (Abelmoschus manihot 1.) leaf extract with liquid chromatography-mass spectrometry using quadrupole time-of-flight technology (LCMS-QToF)," Food Science and Technology (United States), vol.8, no.4, pp.79-86, 2020, DOI: $10.13189 /$ fst. 2020.080402
[28] Douglas A. Skoog, F. James Holler, S. R. C. Instrumental Analysis Principles, 2018,

[29] Hewavitharana, G. G., Perera, D. N., Navaratne, S. B., \& Wickramasinghe, I, "Extraction methods of fat from food samples and preparation of fatty acid methyl esters for gas chromatography: A review," Arabian Journal of Chemistry, vol.13, no.8, pp.6865-6875, 2020, DOI: 10.1016/j.arabjc.2020.06.039

[30] Maurer, N. E., Hatta-sakoda, B., Pascual-chagman, G., \& Rodriguez-saona, L. E, "Characterization and authentication of a novel vegetable source of omega-3 fatty acids, sacha inchi ( Plukenetia volubilis L .) oil," Food Chemistry, vol.134, no.2, pp.1173-1180, 2015, DOI: 10.1016/j.foodchem.2012.02.143

[31] Mohseni, N. M., Mirzaei, H., \& Moghimi, M, "Optimized extraction and quality evaluation of Niger seed oil via microwave-pulsed electric field pretreatments," Food Science and Nutrition, vol.8, pp.1383-1393, 2020, DOI: $10.1002 /$ fsn 3.1396

[32] Montcho, P. S., Tchiakpe, L., Nonviho, G., Diane, F. T., Sidohounde, A., Pascal, C., Sohounhloue, K, "Fatty acid profile and quality parameters of Ceiba pentandra ( L .) seed oil : A potential source of biodiesel," vol.9, no.December, pp.14-19, 2018, DOI: 10.5897/JPTAF2018.0141

[33] Yusuf, Z., Hugo, A., Zeleke, H., Mohammed, W., \& Hussein, S, "Fatty Acid Profile of Groundnut ( Arachis hypogaea L .) Cultivars in Ethiopia Fatty Fatty Acid Profile of Groundnut ( Arachis hypogaea L . ) Cultivars in Ethiopia," International Journal of Horticultural Science and Ornamental Plants, vol.5, no.2, pp.086-091, 2019, ISSN: 2141-502X

[34] Nelson, S. O., Kandala, C. V. K., \& Lawrence, K. C, "Moisture determination in single grain kernels and nuts by rf impedance measurements," IEEE Transactions on Instrumentation and Measurement, vol.41, no.6, pp.10271031, 1992, DOI: 10.1109/19.199387

[35] Islam, M. T., Kuzmichev, I., Kogut, A., Dolia, R., Eremenko, Z., Kogut, E., \& Liu, L. W. Y, "Determination of the moisture content in walnuts using microwave nondestructive technique," Telecommunications and Radio Engineering (English translation of Elektrosvyaz and Radiotekhnika), vol.79, no.6, pp.509-520, 2020, DOI: 10.1615/TelecomRadEng.v79.i6.50

[36] [36] Nejad, M. K., Tabil, L. G., Mortazavi, A., \& Kordi, A. S, "Effect of drying methods on the quality of Pistachio nuts," ASAE/CSAE North-Central Intersectional Meeting in Canada, September 27-28, 2002, DOI: 10.1081/DRT-120021688

[37] Ajibola, O. O., Aviara, N. A., \& Abodunrin, V. K, "Moisture sorption equilibrium and thermodynamic properties of palm kernel," International Agrophysics, vol.19, no.4, pp.273-283, 2005, ISSN: 02368722

[38] Zuza Jnr, E., Muitia, A., I.V. Amane, M., L. Brandenburg, R., Emmott, A., \& M. Mondjana, A, "Effect of Harvesting Time and Drying Methods on Aflatoxin Contamination in Groundnut in Mozambique," Mycotoxins - Impact and Management Strategies, vol.2, 2019, DOI: 10.5772/intechopen. 77300

[39] Udoh, J. E., Olayanju, T. M. A., Dairo, O. U., \& Alonge, A. 
F, "Effect of moisture content on the mechanical and oil properties of soursop seeds." Chemical Engineering Transactions, vol.58, pp.361-366, 2017, DOI: 10.3303/CET1758061

[40] [40] Zygler, A., Słomińska, M., \& Namieśnik, J,. "Soxhlet Extraction and New Developments Such as Soxtec," In Comprehensive Sampling and Sample Preparation (Vol. 2, pp. 65-82). Elsevier Inc, 2012, DOI: 10.1016/B978-0-12-381373-2.00037-5

[41] Siddique, B. M., Ahmad, A., Alkarkhi, A. F. M., Ibrahim, M. H., \& Omar A.K, M, "Chemical Composition and Antioxidant Properties of Candlenut Oil Extracted by Supercritical CO 2," Journal of Food Science, vol.76, no.4, pp.535-542, 2011, 10.1111/j.1750-3841.2011.02146.x

[42] Sutanto, S., Go, A. W., Ismadji, S., \& Ju, Y. H, "Hydrolyzed rice bran as a source of lipids and solid acid catalyst during in situ (trans)esterification," Biofuels, vol.7269, pp.1-7, 2017, DOI: 10.1080/17597269.2017.1348190

[43] Gao, P., Liu, R., Jin, Q., \& Wang, X, "Comparison of solvents for extraction of walnut oils: Lipid yield, lipid compositions, minor-component content, and antioxidant capacity," LWT-Food science and technology, vol.110, issue April, pp.346-352, 2019, DOI: 10.1016/j.lwt.2019.04.100

[44] Juhaimi, F. Al, Uslu, N., Babiker, E. E., Ghafoor, K., Mohamed Ahmed, I. A., \& Özcan, M. M, "The effect of different solvent types and extraction methods on oil yields and fatty acid composition of safflower seed," Journal of Oleo Science, vol.68, no.11, pp.1099-1104, 2019, DOI: 10.5650/jos.ess 19131

[45] Vlachos, N., Skopelitis, Y., Psaroudaki, M., Konstantinidou, V., Chatzilazarou, A., \& Tegou, E, "Applications of Fourier transform-infrared spectroscopy to edible oils," Analytica Chimica Acta, vol.573-574, pp.459-465,. 2006, DOI: 10.1016/j.aca.2006.05.034

[46] Alexandri, E., Ahmed, R., Siddiqui, H., Choudhary, M. I., Tsiafoulis, C. G., \& Gerothanassis, I. P, "High-resolution NMR spectroscopy as a structural and analytical tool for unsaturated lipids in solution," Molecules, vol.22, no.10, pp.1-71, 2017, DOI: 10.3390/molecules22101663

[47] Kenar, J. A., Knothe, G., \& Kenar, J. A, "Determination of the fatty acid profile by $1 \mathrm{H}-\mathrm{NMR}$ spectroscopy," European Journal of Lipid Science and Technology, vol.106, no.2, pp.88-96, 2004, DOI: 10.1002/ejlt.200300880

[48] Di Pietro, M. E., Mannu, A., \& Mele, A, "NMR determination of free fatty acids in vegetable oils," Processes, vol.8, no.4, pp.410, 2020, DOI: 10.3390/PR8040410

[49] Fanali, C., Dugo, L., Cacciola, F., Beccaria, M., Grasso, S., Dachà, M., Mondello, L, "Chemical characterization of Sacha inchi (Plukenetia volubilis L.) oil," Journal of Agricultural and Food Chemistry, vol.59, no.24, pp.1304313049, 2011, DOI: 10.1021/jf203184y

[50] Gutiérrez, L. F., Rosada, L. M., Jiméneza, Á., Luis-Felipe Gutiérrez, a, Lina-María Rosada, \& Álvaro Jiménez, "Chemical composition of sacha inchi (plukenetia volubilis 1.) seeds and characteristics of their lipid fraction," Grasas $y$ Aceites, vol.62, no.1, pp.76-83,.2011, DOI: $10.3989 / \mathrm{gya} 044510$

[51] Hădărugă, D. I., Ünlüsayin, M., Gruia, A. T., Birău, C., Rusu, G., \& Hădărugă, N. G, "Thermal and oxidative stability of Atlantic salmon oil (Salmo salar L.) and complexation with $\beta$-cyclodextrin," Beilstein J. Org. Chem, vol.12, pp.179-191, 2016, DOI: 10.3762/bjoc.12.20

[52] Mohamad, N., Lim, J. S., \& Idris, A, "Extracting edible oil from Nannochloropsis oculata: A functional food for future," Food Science and Technology (United States), vol.8, no.3, pp.50-60, 2020, DOI: $10.13189 /$ fst.2020.080302 